AL-IQTISHOD: Jurnal Pemikiran dan Penelitian Ekonomi Islam

E-ISSN: 2407-6600 P-ISSN: 2745-85I2

Volume I0 Issue I Januari 2022 | Page: 096-II2

DOI: https://doi.org/I0.378I2/aliqtishod

\title{
Pengaruh Etika Bisnis Islam Dalam Meningkatkan UMKM
}

\author{
Nur Manna Silviyah \\ Universitas Muhammadiyah Sidoarjo \\ silviyah.manna30@gmail.com \\ Novieati Dwi Lestari \\ Universitas Muhammadiyah Sidoarjo \\ novieatilestari@gmail.com
}

\begin{abstract}
Small and medium Micro Enterprises are one of the ways to solve problems in the community's economy. In running the business, Micro, Small and Medium Enterprises will definitely find a problem in doing business. With this, there is an Islam ic economic system that can solve problems in business. In the implementation of Islam ic business ethics need to be done several things in the rules of Islam ic business ethics. The research method used in writing this article is a qualitative research method, and the approach carried out, namely the Library / literature review, which in this discussion is carried out by looking for several journals and articles that are appropriate and relevant to the discussion on the influence of Islam ic business ethics in increasing Micro, Small and Medium Enterprises. The results of this study confirm that the application of Islam ic business ethics needs to be done as a step to improve new awareness in business activities. The application of Islam ic business ethics shows a good influence, and has a positive effect in improving Micro, Small and Medium Enterprises
\end{abstract}

Keywords: business ethics, UMKM, Islamic business ethics

Abstrak: Usaha Mikro Kecil Menengah merupakan salah satu cara dalam mengatasi permasalahan dalam perekonomian masyarakat. Dalam menjalankan bisnis, pelaku Usaha Mikro Kecil Menengah menemukan suatu permasalahan dalam berbisnis. Dengan hal ini munculah sistem ekonomi Islam yang dapat menyelesaikan permasalahan dalam berbisnis. Dalam penerapan etika bisnis Islam perlu dilakukan beberapa hal dalam aturan etika bisnis Islam. Metode penelitian yang digunakan dalam penulisan artikel ini adalah metode penelitian kualitatif, serta pendekatan yang dilakukan yaitu pendekatan studi literatur review, dengan cara mencari beberapa jurnal dan artikel yang sesuai dan relevan dengan pembahasan tentang penerapan etika bisnis Islam dalam meningkatkan Usaha Mikro Kecil Menengah. Hasil peneliatian ini menegaskan bahwa penerapan etika bisnis Islam perlu dilakukan sebagai langkah perbaikan kesadaran baru dalam aktifitas bisnis. Penerapan etika bisnis Islam menunjukkan pengaruh yang baik, dan berpengaruh posistif dalam meningkatkan Usaha Mikro Kecil Menengah

Kata Kunci : etika bisnis, UMKM, etika bisnis Islam 
Pengaruh Etika Bisnis Dalam ...

\section{A. Pendahuluan}

Para pemimpin Muslim menyadari bahwa mereka perlu kembali ke doktrin AlQur'an dan Sunnah, sehingga mereka datang dengan ide untuk menggunakan sistem ekonomi berdasarkan hukum Islam, atau sistem ekonomi Islam . Kesadaran ini muncul karena mereka menyadari bahwa perekonomian yang berjalan selama ini belum membawa perbaikan kondisi perekonomian, khususnya di negara-negara Muslim, yang justru menyumbang kemiskinan yang cukup besar. Realisasi dari hal ini menyebabkan munculnya ekonomi Islam sebagai jawaban atas permasalahan yang terjadi di negara-negara Muslim.

Selain sistem ekonomi syariah yang digunakan sebagai solusi untuk mengatasi kemiskinan, usaha mikro, kecil dan menengah (UMKM) juga dapat secara efektif mengatasi hal tersebut. Oleh karena itu, hal ini dapat memberikan peluang bagi usaha kecil dan menengah (UMKM) untuk mengembangkan usahanya. Dalam proses peningkatan pertumbuhan usaha yang dijalankannya, pelaku UMKM tentunya akan menemui kendala. Salah satu kendala yang dihadapi oleh usaha kecil, menengah dan mikro adalah terkait permodalan. Sebagian besar kendala yang dihadapi oleh usaha kecil, menengah dan mikro terkait dengan manajemen mereka ketika mengajukan permohonan tambahan dana dari industri perbankan.

Dalam rangka mengimplementasikan syariat Islam dalam kehidupan ekonomi Islam, perlu dilakukan perubahan cara berpikir dari sistem ekonomi kapitalis ke sistem ekonomi syariah termasuk masalah bisnis. Karena dunia bisnis tidak terlepas dari etika bisnis. Saat ini banyak perilaku bisnis yang tidak etis dalam berbisnis. Contoh nyata penerapan etika bisnis misalnya perusahaan biskuit Australia Arnotts yang berani menarik seluruh produknya sekalipun ada orang yang memberitahu produk mana saja yang beracun asal diberi sejumlah uang. Perusahaan ini lebih senang apabila menarik produknya demi keselamatan konsumennya serta dampaknya luar biasa karena enam bulan setelahnya pendapatan perusahaan mengalami kenaikan sebanyak tiga kali lipat.

96| Al-Iqtishod Volume. IO/No. I/Januari 2022 
Nur Manna Silviyah,

Novieati Dwi Lestari

Berangkat dari hal diatas, penelitian ini bertujuan untuk menegaskan bahwa penerepan Etika Bisnis sangat berpengaruh dalam meningkatkan kinerja perusahaan dalam hal ini adalah UMKM. Sudut pandang baru yang dihadirkan dalam penelitian ini adalah etika bisnis Islam sebagaimana yang terdapat dalam ajaran ekonomi Islam seperti nilai kejujuran, keadilan dan Tanggung jawab. ${ }^{1}$

\section{B. Kajian Pustaka}

\section{Etika Bisnis Islam}

a. Pengertian Etika Bisnis Secara Umum

Etika berasal dari bahasa Yunani "ethos" yang berarti "adat". Dalam praktik umum, etika selalu dikaitkan dengan kebiasaan hidup yang baik yang ada baik pada diri seseorang itu sendiri maupun dalam masyarakat. Dalam hal ini, dalam pengertian lain, etika adalah suatu kode yang harus dipatuhi atau ditaati.

Masalah etika yang perlu diperhatikan, yaitu pemilik usaha dalam menjalankan kegiatan usahanya. Dengan demikian, etika bisnis adalah tindakan yang dilakukan dalam menjalankan kegiatan bisnis yang tidak melanggar aturan organisasi dan masyarakat, dan setiap kegiatan harus dilakukan dalam keadaan yang wajar, termasuk sesuai dengan norma dan etika yang berlaku.

Menurut Hamzah Ya'qub, etika adalah ilmu tentang perilaku manusia dan prinsip perilaku moral yang benar. Etika adalah ilmu tentang usaha mencari baik dan buruk, dilakukan dengan mengamati tingkah laku yang dapat diketahui manusia melalui akal dan pikiran².

\footnotetext{
I Sri Nawatmi, "Etika Bisnis Dalam Perspektif Islam," Iqtishodiyah : Jurnal Ekonomi Dan Bisnis Islam 4, no. I (2010): 50-59, https://doi.org/I0.36835/iqtishodiyah.v4iI.74.

${ }^{2}$ Indra Aditya Makkasau, "Penerapan Etika Bisnis Islam Pada Usaha Mikro Di Kelurahan Rampoang Kota Palopo," 2019, 33-35.
}

Volume. I0/No. I/Januari 2022 A1-Iqtishod|97 
Pengaruh Etika Bisnis Dalam ...

b. Pengertian Etika Bisnis Menurut Islam

Etika berperan sebagai prinsip moral yang mampu mebedakan mana yang benar dan mana yang salah sedangkan, bisnis merupakan serangkaian peristiwa yang melibatkan pelaku bisnis ${ }^{3}$. Dengan demikian etika bisnis mempelajari tentang mana yang baik/buruk, benar/salah dalam dunia perbisnisan dengan berdasarkan prinsip moralitas. Etika bisnis merupakan pemikiran yang mengenai moralitas dalam ekonomi dan bisnis.

Menurut Sudarsono, etika Islam adalah ajaran etika berdasarkan ajaran agama Islam yang terkandung dalam Al-Qur'an dan Sunnah Nabi Muhammad SAW, dengan nilai-nilai luhur, sifat terpuji dan kebaikan mutlak. dan Sunnah Nabi Muhammad SAW. ${ }^{4}$

Dengan demikian, etika bisnis Islam merupakan akhlak dalam melaksanakan atau menjalankan suatu bisnis dengan berdasarkan nilai-nilai Islam , sehingga dalam melaksakan bisnisnya tidak ada kekhawatiran yang timbul, karena telah dipastikan sebagai sesuatu yang baik dan benar.

c. Bisnis Menurut Islam

Secara umum bisnis merupakan suatu kegiatan yang dilakukan manusia yang bertujuan untuk memperoleh pendapatan atau pengahasilan dalam rangka memenuhi kebutuhan dan keinginan dalam hidup manusia dengan cara melakukan pengelolaan sumber daya ekonomi dengan efektif dan efisien. Dalam Islam bisnis merupakan suatu serangkaian aktivitas bisnis yang didalamnya terdapat berbagai jenis yang tidak dibatasi jumlah kepemilikan hartanya termasuk profitnya, akan tetapi dibatasi dalam perolehannya dan pendayagunaan pada hartanya (terdapat aturan halal dan haram)

\footnotetext{
${ }^{3}$ Darmawati, “Etika Bisnis Dalam Perspektif Islam : Eksplorasi Prinsip Etis Al-Qur'an Dan Sunnah,” Jurnal Pemikiran Hukum Islam I I, no. I (2013): 58-68.

${ }^{4}$ Makkasau, "Penerapan Etika Bisnis Islam Pada Usaha Mikro Di Kelurahan Rampoang Kota Palopo."

${ }^{5}$ Norvadewi, "Bisnis Dalam Perspektif Islam (Telaah Konsep, Prinsip Dan Landasan Normatif)," 20I5, 33 46.
} 
Nur Manna Silviyah,

Novieati Dwi Lestari

Islam mewajibkan kepada setiap muslim, bahwa bekerja adalah salah satu sebab pokok yang memungkinkan manusia memiliki kekayaan. Allah SWT melapangkan bumi serta menyediakan berbagai fasilitas yang bisa dimanfaatkan untuk manusia mencari rezeki dan nafkah. Hal ini sebagaimana yang ditegaskan oleh Allah SWT dalam Q.S Al-Nisa ayat 29.

d. Tujuan Etika Bisnis Dalam Islam

Etika bisnis merupakan hal yang penting guna untuk menjalankan sebuah aktivitas bisnis yang profesional. Sehingga, etika bisnis Islam memiliki fungsi substansial guna untuk membekali para pelau bisnis. Oleh karena itu dalam etika bisnis memiliki tujuan sebagai berikut ${ }^{6}$ :

a) Membangun kode etik Islam i yang mengatur, mengembangkan serta menancapkan metode berbisnis dalam kerangka ajaran agama. Dalam hal ini kode etik sebagai simbol arahan guna untuk melindungi pelaku bisnis dari berbagai risiko.

b) Kode etik bisa menjadi dasar hukum dalam menetapkan tanggungjawab bagi para pelaku bisnis terutama bagi diri mereka sendiri, antar komunitas bisnis, masyarakat serta diatas segalanya tersebut merupakan tanggungjawab di hadapan Allah SWT.

c) Dalam kode etik ini` digunakan sebagai dokumen hukum yang dapat meunyelesaikan persoalan-persoalan yang muncul daripada harus diserahkan kepada pihak peradilan.

d) Kode etik dapat memberikan kontribusi yang besar dalam penyelesaian banyak persoalan yang sedang terjadi baik antar sesama pelaku bisnis dan masyarakat tempat mereka bekerja. Suatu hal yang dapat membangun persaudaraan (ukhuwah) dan kerja sama antara mereka semua.

\section{UMKM}

a. Pengertian

\footnotetext{
${ }^{6}$ Darmawati, “Etika Bisnis Dalam Perspektif Islam : Eksplorasi Prinsip Etis Al-Qur'an Dan Sunnah.”
}

Volume. I0/No. I/Januari 2022 A1-Iqtishod|99 
Pengaruh Etika Bisnis Dalam ...

Menurut UU No. 20 tahun 2008 mengenai Usaha Mikro Kecil dan Menengah (UMKM), maka yang dimaksud dengan Usaha Mikro Kecil dan Menengah adalah ${ }^{7}$ :

I) Usaha dalam lingkup mikro ialah usaha produktif milik perorangan atau badan usaha perorongan yang memenuhi kriteria-kriteria Usaha Mikro sesuai dengan yang diatur dalam Undang-Undang ini.

2) Usaha dalam lingkup kecil ialah usaha ekonomi produktif yang berdiri sendiri yang dilaksanakan oleh perorangan maupun badan usaha dimana badan usaha tersebut bukan merupakan anak perusahaan atau bukan cabang perusahaan yang dimiliki, dikuasai ataupun menjadi bagian baik secara langsung ataupun tidak langsung daru Usaha Menengah atau Usaha Besar yang memenuhi kriteria usaha kecil sebagaimana yang dimaksud dalam Undang-Undang ini.

3) Usaha menengah ialah usaha ekonomi produktif yang berdiri sendiri, dimana usaha tersebut dilakukan oleh perorangan maupun badan usaha yang bukan anak perusahaan atau cabang perusahaan yang dimiliki, dikuasai ataupun menjadi bagian baik langsung ataupun tidak langsung dengan Usaha Kecil atau Usaha Besar dengan jumlah kekyaan bersih maupun hasil penjualan tahunan sebagaimana yang diatur dalam UndangUndang ini.

b. Tujuan UMKM

Sesuai dengan UU No. 20 tahun 2008 mengenai Usaha Mikro Kecil dan Menengah, dalam Undang-Undang tersebut menjelaskan mengenai tujuan dari Usaha Mikro Kecil dan Menengah itu sendiri yaitu ${ }^{8}$ :

\footnotetext{
7 Feni Dwi Anggraeni, Imam Hardjanto, and Ainul Hayat, "Pengembangan Usaha Mikro, Kecil, Dan Menengah (UMKM) Melalui Fasilitasi Pihak Eksternal Dan Potensi Internal," Jurnal Administrasi Publik (JAP) I, no. 6 (2013): I286-95.

${ }^{8}$ Ferry Duwi Kurniawan and Luluk Fauziah, "Pembedayaan Usaha Mikro Kecil Dan Menegah (UMKM) Dalam Penanggulangan Kemiskinan,” JKMP2, no. 2 (2014): I65-76.
} 
Nur Manna Silviyah,

Novieati Dwi Lestari

I) Menumbuhkan dan mengembangkan kemampuan-kemampuan yang dimiliki Usaha Mikro Kecil dan Menengah menjadi usaha yang tangguh dan mandiri.

2) Dengan adanya Usaha Mikro Kecil dan Menengah dapat mewujudkan struktur ekonomi nasional secara seimbang, berkembang dan berkeadilan.

3) Dengan adanya Usaha Mikro Kecil dan Menengah dapat meningkatkan peran dalam hal pembangunan daerah, pemerataan pendapatan, menciptakan lapangan pekerjaan serta pengentasan rakyat dari kemiskinan

\section{Metode Penelitian}

Metode penelitian yang digunakan dalam pembahasan jurnal ini menggunakan analisis kualitatif dengan menggunakan pendekatan studi pustaka atau literatur review. Data dikumpulkan dengan mencari artikel yang relevan dengan pembahasan. Data yang terkumpul kemudian dianalisi, dipilah dan dideskripsikan berdasarkan focus permasalah penelitian ini yakni pengaruh etika bisnis Islam guna untuk meningkatkan kinerja UMKM. .

D. Hasil dan Pembahasan

\section{Persepsi pelaku UMKM terhadap Etika Bisnis Islam}

Persepsi pelaku Unit Usaha Kecil dan Menengah (UMKM) terhadap etika bisnis dapat dilihat dari beberapa indikator yaitu jujur saat menakar ataupun menimbang, menjual barang yang halal serta baik, tidak menyembunyikan apabila adanya kecacatan pada produk yang dijual, tidak menjelek-jelekan usaha orang lain, membayar zakat maal, membayar upah karyawan secara tepat waktu, tidak adanya paksaan dalam melakukan bisnis, mencatat seluruh aktivitas yang berkaitan dengan keuangan, aktivitas bisnis terhindar dari riba, mengutamakan ibadah dibandingkan dengan bisnis.

\footnotetext{
${ }^{9}$ Eko Agus Cahyono, Sutomo, and Aris Hartono, "Literatur Review : Panduan Penulisan Dan Penyusunan," Jurnal Keperawatan, 2019, I2.
}

Volume. I0/No. I/Januari 2022 Al-Iqtishod | I0I 
Pengaruh Etika Bisnis Dalam ...

Dalam melakukan usaha juga masih banyak pelaku usaha yang masih menyembunyikan cacat atas barang yang dijualnya hal ini terjadi diakibatkan pelaku UMKM merasa tidak perlu menjelaskan jika konsumen tidak bertanya mengenai kekurangan produk yang dijual. Terdapat pula indikator mengenai jujur dalam menakar dan menimbang tetapi hal ini juga masih ada kecurangan didalamnua disebabkan tidak ada takaran yang tepat dalam menyajikan suatu produk seperti produk makanan yang langsung disajikan sehingga ukurannya hanya diperkirakan saja serta jumlahnya tidak diukur secara tepat ${ }^{10}$.

Pelaku UMKM juga memiliki persepsi mengenai etika bisnis Islam seperti berbagai tindakan ataupun keputusan disebut sebagai etika Islam bergantung pada niat individu yang melakukannya, niat baik yang diikuti dengan tindakan yang baik pula akan dihitung sebagai ibadah sehingga niat yang halal tidak akan dapat mengubah tindakan yang haram menjadi halal, keputusan yang menguntungkan kelompok baik mayoritas bahkan minoritas tidak secara langsung berarti bersifat etika Islam dalam dirinya dikarenakan etika bukanlah hal yang mengenai jumlah serta dalam Islam menggunakan pendekatan terbuka terhadap etika bukan sebagai sistem yang terutup dan berorientasi diri sendiri dikarenakan egoisme tidak dapat mendapat tempat dalam ajaran Islam . ${ }^{11}$

\section{Peran Etika Bisnis terhadap Kinerja UMKM}

Peran etika bisnis dalam kegiatan bisnis sangat penting, apalagi di masa sekarang ini, kriteria keberhasilan bisnis tidak hanya berdasarkan moralitas dan manajemen yang baik, tetapi juga pada penerapan etika bisnis sehingga dapat menjaga kualitas memenuhi tuntutan semua pasar yang diterima dan dianggap baik oleh masyarakat. Oleh karena itu, para pelaku UMKM harus menghindari

\footnotetext{
Io Salahuddin El Ayyubi and Sausan Anggi Anggraini, "Peran Etika Bisnis Islam Terhadap Kinerja Usaha Mikro, Kecil, Dan Menengah (UMKM) Pangan Di Kota Bogor,” Journal of Business \& Banking 6, no. 2 (2019): 183-94.

${ }^{\text {II }}$ M. Arif Hakim, "Persepsi Pelaku Bisnis SPBU Di Kabupaten Kudus Terhadap Etika Bisnis Islam,” 2016, $5-24$.
} 
Nur Manna Silviyah,

Novieati Dwi Lestari

perilaku buruk dalam berbisnis, seperti penyalahgunaan undang-undang dan peraturan.

Peran tersebut akan berjalankan dengan baik apabila beberapa prinsip dari etika binsis ini diterapkan dalam suatu usaha yaitu Pertama, Prinsip otonomi prinsip ini dibuktikan harus adanya tanggung jawab moral dari suatu usaha guna untuk mengedepankan kualitas dari usaha tersebut. Kedua, prinsip kejujuran ialah dalam kegiatan usaha kejujuran merupakan modal yang penting dalam mengembangakan usaha. Banyak pelaku UMKM gulung tikar dikarenakan tidak menerapkan prinsip kejujuran karena lebih mementingkan internal usahanya dibandingkan memikirkan para konsumennya. Ketiga, Prinsip keadilan pada prinsip ini menekankan untuk tidak membeda-bedakan dan harus terus bersikap adil. Maksudnya yaitu dengan berlaku adil dalam menjalankan suatu usaha maka tidak akan merugikan salah satu pihak. Keempat, Prinsip saling menguntungkan dalam prinsip ini juga harus diterpak oleh pelaku usaha dikarenakan ketika kedua belah pihak yaitu pelaku UMKM dengan konsumen bisa saling menguntungkan maka akan dapat memajukan usaha tersebut. Kelima, Prinsip integritas moral merupakan tuntutan internal dari pelaku UMKM agar dalam menjalankan usaha yang dimiliknya tetap menjaga nama baiknya serta nama baik usaha yang sedang dijalankannya. Keenam, Prinsip kelestarian lingkungan hidup ialah dalam melakukan usaha harus berusaha menjaga lingkungan disekitar tempat berdirinya usaha tersebut dikarenakan pada era sekarang banyak yang mementingkan usahanya saja tanpa memperdulikan lingkungan disekitarnya seperti membuang limbah disungai, dsb. Ketujuh, Prinsip keselamatan konsumen menjelaskan bahwasanya setiap menjalankan usaha harus memperhatikan keselamatan bagi para konsumen ${ }^{12}$.

\section{Penerapan Etika Bisnis Islam Dalam UMKM}

I2 Wanda Nur Fitria, Ziyan Maulida Rahmah, and Sheila Febriani Putri, "Peran Etika Bisnis Dalam Mengambangkan Usaha Di Era Revolsi 4.0,” Prosiding National Seminar on Accounting, Finance, and Economics (NSAFE) I, no. 3 (202I): 268-76.

Volume. IO/No. I/Januari 2022 Al-Iqtishod | 103 
Pengaruh Etika Bisnis Dalam ...

Dalam menerapkan etika bisnis Islam yang perlu dilakukan yaitu pertama, perbaikan kesadaran baru yang mengenai bisnis, pandangan terhadap etika bisnis sebagai bagian yang tak terpisahkan atau menyatu yang merupakan struktur fundamental sebagai perubahan tanggapan dan pemahaman yang mengenai kesadaran sistem bisnis amoral di masyarakat. Kedua, harus dipertimbangkan dalam menerapkan etika bisnis untuk membangun tatanan bisnis Islam yaitu dengan cara melakukan kajian keilmuan yang membahas mengenai bisnis dan ekonomi yang berfokus pada paradigma pendekatan normatif etik dan empiric induktif dengan mengedepankan penggalian dan juga pengembangan nilai-nilai Al-Qur'an, agar mampu mengatasi perubahan akibat pergeseran zaman yang semakin cepat ${ }^{13}$.

Dalam penerapan etika bisnis Islam merupakan kriteria yang sangat baik, akan tetapi ada beberapa hal yang perlu dikembangkan lagi walaupun telah memasuki kriteria yang sangat baik. Akan tetapi terdapat permasalahan yang perlu untuk diperbaiki yaitu, kurangnya konsisten pelaku usaha mikro dalam mecatat berbagai hal yang terkait dengan usahanya tersebut, karena dengan mencatat akan dapat menghidarkan dari sesuatu yang tidak diinginkan. Pelaku UMKM dapat menerapkan dengan membuka sarana complain dan mencatatnya kemudian melakukan evaluasi dengan berdasarkan catatan keluhan konsumen, karena hal ini dapat bermanfaat pada hubungan antara penjual dan pembeli, agar dapat memaksimalkan usahanya ${ }^{\mathrm{I4}}$.

Dalam melaksanakan etika bisnis tidak bisa lepas dari norma. Sebagai etika khusus atau etika terapan yang memiliki prinsip-prinsip dalam penerapan etika tersebut. Dalam hal ini UMKM telah melaksanakan konsep-konsep etika bisnis diantaranya, yaitu :

\footnotetext{
${ }^{13}$ Darmawati, “Etika Bisnis Dalam Perspektif Islam : Eksplorasi Prinsip Etis Al-Qur'an Dan Sunnah.”

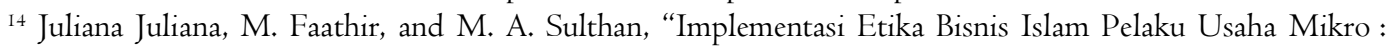
Studi Kasus Pada Pelaku Usaha Mikro Syariah Puspa Bank Indonesia Wilayah Jawa Barat Di Bandung Tahun 2017," Strategic: Jurnal Pendidikan Manajemen Bisnis I9, no. I (2019): 36, https://doi.org/I0.17509/strategic.vI9iI.I7663.
} 
I. Kejujuran

Merupakah salah satu prinsip etika bisnis. Dalam hal berbisnis kejujuran berkaitan dengan beberapa hal berikut ini,

a. Kejujuran sangat penting dalam menjaga kelangsungan hubungan bisnis dengan para relasi.

b. Menciptakan kepercayaan dan kepuasan konsumen dalam kesesuaian mutu dan harga. Mampu menjaga hubungan kerja antar individu dengan adanya kejujuran.

c. Jujur dalam kualitas barang.

2. Tanggung Jawab

Merupakan salah satu tindakan yang dilakukan dalam kehidupan sehari-hari dan bahkan sebuah kewajiban. Sebagai pengelola maupun pelaku jasa, tanggung jawab merupakan sikap yang wajib dimiliki oleh manusia, karena hal ini menyangkut pada kredibilitas yang melibatkan kepuasan konsumen. Karena semakin kita tanggap dan responsif terhadap konsumen maka akan meningkatkan kepuasan konsumen terhadap pelayanan yang telah diberikan.

3. Bersaing Secara Sehat

Merupakan persaingan yang mengedepankan etika. Persaingan ini dilandasi dengan nilai-nilai moral yang baik.

4. Ramah

Sikap ramah ini dapat meningkatkan jalinan komunikasi dan loyalitas konsumen, maka sangat penting menggunakan dan mengelola kata dalam mengekspresikan keramahan.

5. Peduli dengan Pelanggan

Kepedulian terhadap konsumen dapat meningkatkan loyalitas konsumen terhadap pelaku UMKM, karena dengan memperhatikan permasalahan yang dihadapi konsumen dan sebisa mungkin untuk 
Pengaruh Etika Bisnis Dalam ...

menyelesaikan permasalahan dan memberikan solusi kepada konsumen tersebut.

6. Responsif

Nilai responsif dapat terjadi dalam penyediaan waktu untuk konsumen, untuk menjawab keingintahuan konsumen atas produk yang dipromosikan dengan sikap keramahan.

7. Dedikasi yang Tinggi

Adanya penerapan etika bisnis pada pelaku UMKM dapat meningkatkan loyalitas konsumen, meningkatkan kepercayaan pembeli. Penerapan etika bisnis pada pelaku UMKM berdampak adanya citra baik pada pelaku UMKM pada pandangan konsumen, sehingga dapat meningkatkan pendapatan pelaku UMKM. Etika bisnis memiliki 7 nilai, yaitu kejujuran, tanggung jawab, bersaing secara sehat, ramah, peduli dengan pelanggan, responsive, dan dedikasi yang tinggi ${ }^{15}$.

\section{Pengaruh Etika Bisnis Islam Pada UMKM}

Dalam penerapan etika bisnis Islam menunjukkan pengaruh yang baik, aktivitas bisnis tidak sekedar kegiatan dalam rangka menghasilkan barang dan jasa, akan tetapi juga kegiatan mendistribusikan barang dan jasa tersebut ke pihak yang memerlukan serta aktivitas lainnya yang mendukung kegiatan produksi dan distribusi tersebut. Menurut etika bisnis Islam, bahwa setiap wirausahawan dalam berdagang tidak harus seakan-akan dengan tujuan hanya untuk mencari keuntungan saja, namun, mengharapkan keridhaan Allah SWT dan mencapai keberkahan atas rezeki yang telah Allah SWT berikan. Wirausahawan juga harus menghindari upaya dalam penyalahgunaan dalam mencari keuntungan pribadi dan tanpa memperdulikan kerugian pada pihak lain.

\footnotetext{
${ }^{15}$ Bambang Setiyo Pambudi, "Penerapan Etika Bisnis Pada Usaha Kecil Dan Menengah Melalui Pemanfaatan Computer Mediated Comunication / Media Social Instagram," Seminar Nasional Dan Call for Paper Sustainable Competitive Advantage (SCA) 8, no. September (2018): I-8.
} 
Nur Manna Silviyah,

Novieati Dwi Lestari

Dalam jurnal "Is "Isam ic perception of business ethics and the impact of seculer thought on Islam ic business ethic." Hasil penelitian Muhammad Hashim, menyatakan bahwa menjadi muslim harus mengikuti aturan dan regulasi dalam urusan bisnis yang telah dinyatakan oleh hukum bisnis Islam dengan mempertahankan citra dan mampu dalam bertahan. Keuntungan dalam usaha sangat dipengaruhi oleh etika bisnis Islam, karena etika Islam mempunyai dasar yang dirumuskan dan juga dikembangkan oleh para sarjana muslim.

Tingkat pertumbuhan suatu bisnis dapat dipengaruhi dari berbagai faktor, baik dari internal maupun eksternal. Dalam penerapan etika bisnis Islam juga berdampak pada aspek finasial dimana dapat terlihat pada kemajuan perusahaan dan juga prospek bisnisnya. Jadi pengetahuan yang seorang wirausahawan miliki merupakan suatu cerminan dirinya dalam berbisnis dan setiap orang mempunyai pengetahuan yang berbeda-beda dalam hidupnya, baik yang didapat dengan melalui Pendidikan formal maupun non formal, dan penerapan etika bisnis Islam berpengaruh posistif dalam meningkatkan UMKM ${ }^{17}$.

Tatanan nilai yang harus dilakukan para pelaku bisnis dalam pelaksanaan Etika Bisnis Islam diantaranya: ${ }^{18}$

I) Tauhid

Prinsip ini menghubungkan pada sifat homogen dalam berbagai aspek yang berbeda-beda pada kehidupan seorang muslim misalnya ekonomi, politik, agama, masyarakat dan menegaskan pada gagasan yang berhubungan dengan konsistensi dan juga keteraturan. Prinsip ini

\footnotetext{
${ }^{16}$ Muhammad Hashim, "Islamic Perception of Business Ethics and the Impact of Secular Thoughts on Islamic Business Ethics," International Journal of Academic Research in Business and Social Sciences 2, no. 3 (2012): 98-I20.

${ }^{17}$ Sri Umi Kalsum, "Jurusan Ilmu Ekonomi Fakultas Ekonomi Dan Bisnis Islam Universitas Islam Negeri Alauddin Makassar 2013,” 2013.

I8 Nurin Fajrina, "Dampak Penerapan Etika Bisnis Islam Pada Kemajuan Bisnis (Studi: De' Halal Mart Yogyakarta),” n.d.
}

Volume. IO/No. I/Januari 2022 Al-Iqtishod | 107 
mempunyai dampak yang mendalam bagi diri seorang pengusaha muslim sehingga dapat menghindarkan:

a) Perbuatan diskriminatif kepada pekerja, pembeli, supplier atau pemegang saham perusahaan atas dasar perbedaan ras, warna kulit, jenis kelamin ataupun agama.

b) Tidak akan mudah untuk dipaksa dalam perbuatan yang tidak baik karena hanya takut dan cinta kepada Allah Subhanahu Wa Ta'ala, dan selalu mengikuti aturan perilaku yang telah sesuai dengan agama Islam .

c) Tidak akan menimbun kekayaan, sebab mengetahui bahwa harta yang ada di dunia ini bersifat sementara dan harus dipergunakan dengan sebaik-baiknya nya.

Dengan penerapan etika Tauhid ini dengan adanya berdekatan kepada Allah Subhanahu Wa Ta'ala yakni dengan melakukan suatu kewajiban bagi seorang muslim. Hal ini dapat menunjukkan bahwa kualitas produk dan proses produksi yang sangat dijaga kualitas kerja SDM juga sangat dijaga. Bahkan unsur-unsur keIslam an pada suatu perusahaan sangatlah diutamakan dengan diadakannya kegiatan pengajian dan briefing sebelum memulai kegiatan dalam penjualan.

2) Keadilan/keseimbangan

Dalam penerapan etika keseimbangan ini dapat dilakukan dengan tidak mementingkan diri sendiri tetapi mementingkan kebutuhan orang lain juga, karena hal ini dapat menciptakan suatu keseimbangan antara penjual dan pembeli maka disinilah akan terjadilah sosialisasi yang cukup baik, dan pastinya terhindar dari terjadi adanya kerugian dari kedua belah pihak.

Hal ini dapat dilihat dari kualitas produksi dan juga distribusi yang telah dilakukan oleh perusahaan karena kualitas produksi dan 
Nur Manna Silviyah,

Novieati Dwi Lestari

distribusi yang baik akan bertujuan untuk melayani kebutuhan konsumen dan juga memberikan produk yang terbaik untuk konsumen nantinya. Kesimpulannya untuk konsep ini adalah saat perusahaan memberikan produk yang terbaik untuk konsumen maka konsumen juga harus memberikan loyalitas yang terbaik untuk perusahaan dengan demikian maka keduanya antara pembeli dan penjual dapat terjalin sosialisasi yang baik di antara mereka keduanya.

3) Kehendak Bebas

Penerapan kehendak bebas dapat memiliki standar produk sendiri daripada perusahaan lainnya. Karena perlunya pemilihan kualitas barang yang nantinya akan diperjualbelikan haruslah ah jelas akan jenis produk tersebut seperti jelasnya kehalalannya dan sudah lulus uji Depkes karena hal ini tidak ada bentuk kekhawatiran konsumen yang mengenai kualitas dan tingkat kehalalan produk.

4) Tanggung Jawab

Penerapan tanggung jawab yaitu merupakan suatu keharusan bagi manusia atas semua tindakannya. Karena seseorang tidak boleh mengkambinghitamkan seseorang atas tindakan yang telah dilakukan sendiri akan tetapi harus bertanggung jawab penuh atas tindakan itu sendiri. Penerapan ini dilakukan perusahaan dengan cara sertifikasi perusahaan agar berbadan hukum. Karena perusahaan itu dapat disebut sebagai perusahaan yang dapat bertanggung jawab kepada ada konsumen maka perusahaan haruslah sertivikasi atau telah berbadan hukum yang bertujuan untuk dapat menunjukkan bahwa perusahaan tersebut benar-benar perusahaan yang bertanggung jawab.

5) Kejujuran

Penerapan kejujuran pada perusahaan itu tidak berbohong tidak menutupi kekurangan dari produk tidak memanipulasi produk, tidak 
Pengaruh Etika Bisnis Dalam ...

melakukan tindakan curang dalam berbisnis, memberikan semua informasi lengkap mengenai barang yang dijual. Dalam prinsip ini bahwa suatu tindakan haruslah memberikan suatu kemanfaatan yang lebih terhadap orang lain tidak membuat kecewa, dan menghadirkan mudharat bagi orang lain.

Penerapan Etika Bisnis Islam dapat dilakukan dengan baik pada suatu perusahaan atau usaha maka pelaku bisnis dapat melakukan dengan sesuai prinsip Islam dan telah menerapkan Etika Bisnis Islam pada setiap proses kegiatannya.

\section{E. Simpulan}

Persepsi para pelaku Unit Usaha Kecil dan Menengah (UMKM) terhadap etika bisnis dapat dilihat dari beberapa indikator diantaranya yaitu jujur saat menakar ataupun menimbang, menjual barang yang halal serta baik, tidak menyembunyikan apabila adanya kecacatan pada produk yang dijual. Serta etika bisnis memiliki peran dalam kegiatan usaha memiliki kedudukan yang sangat penting. Peran tersebut akan berjalan dengan baik apabila etika bisnis menerapkan beberapa prinsip dalam suatu usaha. Dalam menerapkan etika bisnis Islam yang perlu dilakukan salah satunya yaitu perbaikan kesadaran baru yang mengenai bisnis. Dalam penerapan etika bisnis Islam menunjukkan pengaruh yang baik, dan berpengaruh posistif dalam meningkatkan UMKM.

\section{F. Daftar Pustaka}

Ali, Mohammad Haidar. "Penerapan Etika Bisnis Dan Strategi Manajemen Saat Pandemi Covid-I9 Bagi UMKM.” Eco-Entrepreneurship 6, no. I (2020): 34-42.

Amalia, Fitri. "Etika Bisnis Islam : Konsep Dan Implementasi Pada Pelaku Usaha Kecil." Etika Bisnis Islam : Konsep Dan Implementasi Pada Pelaku Usaha Kecil, no. 95 (2013): II6-25.

Anggraeni, Feni Dwi, Imam Hardjanto, and Ainul Hayat. "Pengembangan Usaha Mikro, 
Kecil, Dan Menengah (UMKM) Melalui Fasilitasi Pihak Eksternal Dan Potensi Internal." Jurnal Administrasi Publik (JAP) I, no. 6 (2013): 1286-95.

Ayyubi, Salahuddin El, and Sausan Anggi Anggraini. "Peran Etika Bisnis Islam Terhadap Kinerja Usaha Mikro, Kecil, Dan Menengah (UMKM) Pangan Di Kota Bogor." Journal of Business \& Banking 6, no. 2 (2019): 183-94.

Cahyono, Eko Agus, Sutomo, and Aris Hartono. "Literatur Review : Panduan Penulisan Dan Penyusunan.” Jurnal Keperawatan, 2019, I2.

Darmawati. "Etika Bisnis Dalam Perspektif Islam : Eksplorasi Prinsip Etis Al-Qur'an Dan Sunnah.” Jurnal Pemikiran Hukum Islam I I, no. I (20I3): 58-68.

Fajrina, Nurin. "Dampak Penerapan Etika Bisnis Islam Pada Kemajuan Bisnis (Studi : De' Halal Mart Yogyakarta),” n.d.

Fitria, Wanda Nur, Ziyan Maulida Rahmah, and Sheila Febriani Putri. "Peran Etika Bisnis Dalam Mengambangkan Usaha Di Era Revolsi 4.0.” Prosiding National Seminar on Accounting, Finance, and Economics (NSAFE) I, no. 3 (202I): 268-76.

Hakim, M. Arif. "Persepsi Pelaku Bisnis SPBU Di Kabupaten Kudus Terhadap Etika Bisnis Islam ,” 20I6, 5-24.

Hashim, Muhammad. "Islam ic Perception of Business Ethics and the Impact of Secular Thoughts on Islam ic Business Ethics." International Journal of Academic Research in Business and Social Sciences 2, no. 3 (2012): 98-120.

Juliana, Juliana, M. Faathir, and M. A. Sulthan. "Implementasi Etika Bisnis Islam Pelaku Usaha Mikro : Studi Kasus Pada Pelaku Usaha Mikro Syariah Puspa Bank Indonesia Wilayah Jawa Barat Di Bandung Tahun 2017.” Strategic: Jurnal Pendidikan Manajemen Bisnis I9, no. I 36. https://doi.org/I0.I7509/strategic.vI9iI.I7663.

Juliyani, Erly. "Etika Bisnis Dalam Persepektif Islam ." Jurnal Ummul Qura VII, no. I (2016): 63-74.

Kalsum, Sri Umi. "Jurusan Ilmu Ekonomi Fakultas Ekonomi Dan Bisnis Islam Universitas Islam Negeri Alauddin Makassar 2013,” 2013.

Kurniawan, Ferry Duwi, and Luluk Fauziah. "Pembedayaan Usaha Mikro Kecil Dan Menegah (UMKM) Dalam Penanggulangan Kemiskinan.” JKMP 2, no. 2 (20I4): I65-76.

Volume. I0/No. I/Januari 2022 Al-Iqtishod|III 
Pengaruh Etika Bisnis Dalam ...

Makkasau, Indra Aditya. "Penerapan Etika Bisnis Islam Pada Usaha Mikro Di Kelurahan Rampoang Kota Palopo,” 2019, 33-35.

Nawatmi, Sri. "Etika Bisnis Dalam Perspektif Islam ." Iqtishodiyah : Jurnal Ekonomi Dan Bisnis Islam 4, no. I (2010): 50-59. https://doi.org/I0.36835/iqtishodiyah.v4iI.74.

Norvadewi. "Bisnis Dalam Perspektif Islam (Telaah Konsep, Prinsip Dan Landasan Normatif)," 20I5, 33-46.

Pambudi, Bambang Setiyo. "Penerapan Etika Bisnis Pada Usaha Kecil Dan Menengah Melalui Pemanfaatan Computer Mediated Comunication / Media Social Instagram." Seminar Nasional Dan Call for Paper Sustainable Competitive Advantage (SCA) 8, no. September (20I8): I-8.

Rahmawati, Lilik, Dina Dwi Rahayu, Hanien Nivanty, and Wardah Lutfiah. "Fintech Syariah : Manfaat Dan Problematika Penerapan Pada UMKM.” Jurnal Masharif AlSyariah: Jurnal Ekonomi Dan Perbankan Syariah 5, no. I (2020): 75-90. 